\title{
Amount of Starch in Plants Has Been Improved by Genetic Engineering
}

\author{
遺伝子工学により植物の澱粉含量を向上させる
}

Stark, D.M., Timmerman, K.P., Barry, G.F., Preiss, J., and Kishore, G.M. (1992) Science 258, 287-292

Key Words: ADP glucose pyrophosphorylase, allosteric regulation, potato, Escherichia coli, starch

Starch is the most important energy source for animals including human beings. Since the human population is increasing even now, an improvement in starch yield should be one of the biggest tasks which biotechnology can solve. Indeed, starch is becoming widely used not only for food materials but also for industrial uses as a raw material for high fructose corn syrup and bio-ethanol.

Preiss (Preiss J., in The Biochemistry of Plants, Preiss J., ed. Academic Press Orlando, FL, 1988) has shown that the biosyntheses glycogen in bacteria and starch in plants involve three enzymes as follows:

1. adenosine diphosphate glucose pyrophosphorylase [E.C. 2 .

7.7.27]

2. starch synthase [E.C. 2.4.1.21]

3. branching enzyme [E.C. 2.4.1.18]

A good place to start for the improvement of starch biosynthesis is to strengthen the rate-limiting enzyme reaction in these three reactions. The Escherichia coli adenosine diphosphate glucose pyrophosphorylase (ADPGPP) is an allosteric regulated enzyme which is activated by fructose 1,6biphosphate and inhibited by adenosine monophosphate and inorganic phosphate. Plant ADPGPPs are also allosteric enzymea which are regulated positively by 3-phosphoglyceric acid and negatively by inorganic phosphate. Based on these backgrounds, it is suggested that ADPGPP regulates the starch biosynthesis in plants. In fact, $E$. coli carrying a mutated ADPGPP which was less dependent on the allosteric effectors accumulated approximately $33 \%$ higher quantities of glycogen than its wild-type parent.

Based on the facts described above, a study on the improvement of the starch amount in plants was done by enhancing the ADPGPP activity. As for the source of ADPGPP, $E$. coli was used from the two points of view as follows. First, ADPGPP from $E$. coli is homotetramer, whereas the enzymes from plants are heterotetramer that contain two distinct subunits. Therefore, the expression of the single ADPGPP gene from $E$. coli is easier than the coordinate expression of the two distinct genes from plant. Secondly, the mutant ADPGPP gene can be ready to employ in the experiment, and it minimizes the interference by the complex allosteric regulation.

glgC16 Gene which coded the mutated ADPGPP was ligated downstream of the chloroplast transit peptide (CTP) gene derived from an Arabidopsis small subunit ribrose 1,5-
澱粉はヒトを含む高等動物の主要なエネルギー源である。 世界的にみれば人口は増加の一途をたどっており、この澱粉の 増産はバイオテクノロジーが解決できる大きな課題の一つであ ろう。実際、澱粉はそのまま食品原料となるばかりでなく、異 性化液糖あるいはエ夕ノール醗酵の原料として需要がますます 増大してきている。

Preiss(Preiss, J., in The Biochemstry of Plants, Preiss, J. ed. Academic Press Orland, FL, 1988) は細菌のグリコーゲン合成およ

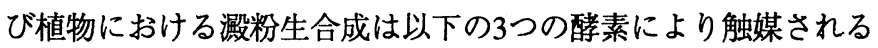
ことを明らかにしている。

1. アデノシンニリン酸グルコースピロフォスファターゼ[E.C.

2.7.7.27]

2. スターチシンターゼ[E.C. 2.4.1.21]

3. ブランチングエンザイム[E.C. 2.4.1.18]

さて、植物における澱粉生合成を向上させるにはこれら 3 つの反応のうち律速段階であるところの䤃素反応を増強するこ とが考えられる。大腸菌のグリコーゲン生合成において、アデ ノシンニリン酸グルコースピロフォスファターゼ(以下 ADPGPP)はフラクトース 1,6-二リン酸により活性化され、アデ ノシンーリン酸および無機リン酸により阻害されるアロステ リック酵素である。また植物由来の ADPGPPは3-フォスフォグ リセリン酸により正に、また無機リン酸により負に制御され る。このような知見から、この ADPGPP が植物の澱粉生合成の 制御をしていることが示唆される。実際、このアロステリック 効果の低下した変異 ADPGPP を保有する大腸菌は野性型に比べ てグリコーゲンの蓄積が約 $33 \%$ 増大していた。

以上の事実に基づいて、植物中の ADPGPP 活性を高めるこ とにより澱粉含量を増大させる研究が以下のように行われた。 まず、ADPGPP としては二つの理由で大腸菌由来のものが使わ れた。一つは、植物由来のADPGPP は二つの分子量の異なるサ ブユニットからなる4量体であるのに対して大腸菌由来のものは 同一のサブユニットからなる4量体であることから、遺伝子の発 現の容易さという点である。もう一つは、既にアロステリック 制御を受けにくくなった ADPGPPが利用できることから、複雑 な制御の問題が避けられることである。

この大腸菌由来のアロステリック効果の低下した变異 ADPGPP をコードする glgC16 遺伝子をまず Arabidopsis のリフ ロース 1,5-二リン酸カルボキシダーセの小サブユニット由来の 
biphosphate carboxylase gene. The fusion protein (CTPADPGPP) was transported and processed in chroloplasts of lettuce leaf. To confirm the CTP-glgC16 gene product is enzymatically active in plant cells, the gene was introduced into tobacco under control of cauliflower mosaic virus-enhanced 35S promoter and the polyadenylation signal from nopaline synthase gene. Extracts of protoplasts carrying the chimeric gene expressed ADPGPP activity under the presence of inorganic phosphate, whereas the control exhibited little or no activity. Therefore, it was concluded that the $E$. coli mutant ADPGPP gene could be expressed in plant cells, and the enzyme held its activity.

The plasmid containing the CTP-glgC16 gene was transformed Agrobacterium tumefaciens to produce stable transgenic plants, and the strain was used for introducing the gene into tobacco, tomato, and potato. The number of starch granules in the tobacco calli was substantially increased. The average starch quantity in the transgenic tobacco was $10.7 \%$, much higher than that of control (3.4\%). Surprisingly, one of the samples expressing the CTP-glgC16 gene contained $26.9 \%$ starch. These results prove that the ADPGPP reaction is the rate-limiting step in starch biosynthesis in tobacco cells. Even in tomato leaves, which typically do not accumulate large amounts of starch, the same result was observed.

The recovery of plants expressing the CTP-glgC16 gene was poor. It was thought that constitutive expression of the CTP-glgC16 gene was detrimental to plant growth and development. Sucrose availability for export may be reduced by the excess starch accumulation in the leaves. Therefore, the actively growing portions of the plant could not utilize a sufficient amount of carbon source. In fact, the transgenic potato expressing the gene could be maintained on the sucrose-containing medium but could not survive in soil without providing sucrose.

The detrimental effects of constitutive expression of ADPGPP activity was overcome by introducing the CTPglgCl6 gene into potato plants under the control of a tuber-specific patatin promoter. On average, $35 \%$ more starch than control was obtained from tubers expressing patatin-CTPglgCl6 gene. Nearly $60 \%$ more starch than controls was produced in the tubers in some transgenic potato lines.

Although the presence of the CTP-glgC16 gene product was essential for increased starch production, the extent of starch content increased was not definitely correlated with the level of the expression of the gene. This phenomenon may be interpreted as follows: expression of small amounts of CTPglgC16 gene was enough to overcome the limitation of adenosine diphosphate glucose availability for starch biosynthesis; the existence of sufficient ADPGPP activity created a new rate-limiting step. In the first step of starch biosynthesis, substrate availability (glucose 1-phosphate) for the ADPGPP reaction may become a new rate-limiting step.

In vitro studies have shown that the activity of starch
葉緑体トランジットペプチド(CTP)遺伝子の下流に結合させた 後、レタスに導入し、澱粉の生合成が行われる葉緑体にこの融 合タンパク質が輸送され、プロセッシングされていることを確 認した。さらにこの CTP-glgC16 遺伝子産物が植物中で活性を 示すことを確認するためカリフラワーモザイクウイルス enhanced 35S プロモーターとノパリンシンターゼ由来のポリア デニレーションシグナルの制御下においてタバコのプロトプラ ストに導入した。このキメラ遺伝子を保持するプロトプラスト 抽出物は無機リン酸存在下でもADPGPP活性を示したが、対象 のものからは活性は検出されなかった。したがって変異 ADPGPP 遺伝子は植物細胞中で発現し、その遺伝子産物も活性 を保持することが確認された。

さて、この CTP-glgC16 遺伝子を安定に発現するトランス ジェニック植物を作成するため、Agrobacterium tumefaciens の系 を用いてタバコ、トマト、およびポテトに本遺伝子を導入し た。タバコではカルス中の澱粉粒の数が大幅に増加することが 観察された。実際に澱粉含量を求めたところ対象の平均 $3.4 \%$ に

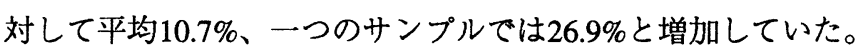
これらの結果からタバコ細胞においては ADPGPP の反応が律速 段階であることが証明できる。あまり多くの澱粉を蓄積するわ けではないトマトの葉においてもこの傾向は見られた。

しかしながら、この CTP-glgC16 遺伝子を発現する植物の 再生産の収率は低いものであった。これは本遺伝子が構成的に 発現する為、植物の成長と分化に有害であるからと考えられ た。すなわち、葉に澱粉が過度に蓄積することにより䓞糖の輸 送が妨げられ、成長に必要な炭素源の利用が制限されると考え られる。実際、本遺伝子を発現させたトランスジェニックポテ 卜は蔗糖含有培地では保存できるが、蔗糖が供給されない土壌 中では生存できなかった。

この問題を解決するため、CTP-glgC16 遺伝子を塊茎で特 異的に発現するタンパク質であるパタチンのプロモーターの制 御下においた。この patatin-CTP-glgC16 遺伝子を保持するポテ 卜塊茎には平均で $35 \%$ 澱粉含量が増加していた。いくつかの トランスジェニックポテトでは潵粉含量の増加は $60 \%$ 近かっ た。

CTP-glgC16 遺伝子の存在は潵粉含量の増加に不可欠では あるものの本遺伝子の発現レベルと測粉含量の増加には完全な 相関はなかった。すなわち、これは少量の CTP-glgC16 遺伝子 の発現により、澱粉合成の為のアデノシンニリン酸グルコース の利用が充分促進され、今度は別のステップが新たな律速段階 になるものと理解できる。潵粉生合成の第一段階において、 ADPGPP の反応の基質すなわちグルコース1ーリン酸の供給その ものが律速になるのかも知れない。

ツユクサの孔辺細胞葉緑体抽出物を用いた in vitro の研究 ではスターチシンターゼの活性は ADPGPP およびブランチング エンザイムのそれの二十分の一であり、この結果からスターチ シンターゼが澱粉合成の律速段階であるとも予想できる。しか 
synthase is only one-twentieth that of ADPGPP and the branching enzyme in Commelina guard-cell chloroplast extracts. These results may suggest that starch synthase is the rate-limiting reaction in starch biosynthesis. However, in view of the results that enhanced ADPGPP activity increases the starch content of plant cells, described above, it is most likely that allosteric regulation down-regulate ADPGPP activity under in vivo conditions. To clarify this point, the wild-type $E$. coli $g l g C$ gene was fused with the CTP and expressed in potato tubers and in tomato leaves. The results indicated that wild-type GlgC was fully subject to allosteric regulation. Threfore, the relative concentrations of allosteric effectors in vivo may regulate the expression of the CTP-glgC gene and may consequently increase ADPGPP activity and starch content in a plant cell environment. Although the tomato leaf tissue showed high levels of expression of the gene, the increase in average starch content was not significant. In spite of the expression level of CTP$g l g C$ and CTP-glgC16 genes were equivalent in tubers, the starch contents were not significantly different. On the basis of these experimental results, it was concluded that ADPGPP activity is rate limiting in starch biosynthesis and that it is not the amount of enzyme protein, but the regulatory properties of ADPGPP, that make it rate limiting.

These experimental data, described here, suggest that photosynthetic carbon assimilation is not limiting to the biosynthesis of starch. Therefore, we can expect an improvement in the yield of crops by making plants fully use their ability. Furthermore, it is interesting that a single enzymatic step regulates the end-product level. All these results make it clear the possibilities of improving the yields of a number of vital metabolites such as lipids, amino acids, and carbohydrates by manipulating a major regulatory step in biosynthesis of proper metabolites.

In this paper, the authors exhibited that there are now many useful systems available to construct various transgenic plants, such as lettuce, tobacco, tomato, and potato. They used two different methods for the analysis of the amount of starch in plant tissues, and their experimental data in this paper were very careful and detailed. I think this paper will be a good exemplary work in this area.

There are still many problems to overcome before we can benefit from transgenic plants, such as safety assesment and public acceptance. However, I sincerely hope that the time will come soon to utilize such prominent works for human prosperity.

\section{Reported by Kuriki, T.}

Biochemical Research Laboratories, Ezaki Glico Co., Ltd., Osaka, Japan
し、先に示したように ADPGPP 活性を増強することにより植物 細胞中の澱粉含量を増加できたことより、in vivoの状態ではア ロステリック制御により ADPGPP 活性は低下するように制御さ れているのではないかと思われる。この点を明らかにする為 に、大腸菌由来の野性型 $\mathrm{glgC}$ 遺伝子をCTP 遺伝子と融合させ、 ポテト塊茎およびトマトの葉で発現させた。 GlgC16酵素とは異 なり野性型 $\mathrm{GlgC}$ 酵素は完全にアロステリック制御の支配下に あった。したがって、invivoでのアロステリックエフェクター の相対的濃度の支配下で、植物細胞環境中 CTP-glgC 遺伝子の 発現がADPGPP活性の上昇ひいては澱粉含量の上昇をもたらす ものと思われる。CTP-glgC 遺伝子を導入したトマトでは本遺伝 子が高レベルで発現しているものの潵粉含量には大差なかっ た。ポテト塊茎においても CTP-glgC 遺伝子が CTP-glgC16 の時 と同程度発現しているにもかかわらず、澱粉含量に差はなかっ た。以上のような結果から澱粉生合成の律速段階は ADPGPP 活 性であり、律速を決定しているのは酵素タンパク質の量ではな く、その制御機構であるということが証明された。

これらの実験によって、光合成による炭素同化が澱粉生合 成の限界を決定しているのではないということが示唆される。 したがって、植物の能力を最大限に発揮させれば、さらに農作 物の収穫を向上させることが可能と期待できる。さらに、この ように一つの酵素反応ステップが複雑な多細胞生物の最終生産 物のレベルを制御していることは興味あることである。すなわ ち、ここで報告した同様の方法により、脂質、アミノ酸、およ び炭水化物のように重要な代謝産物の量をその主要な制御ス テップを操作して変えることが可能であり得るからである。

本論文で著者らは今や種々の便利なシステムがレタス、夕 バコ、トマト、およびポテトなどのトランスジェニック植物を 作成するために利用できることを示している。彼らは植物組織 中の澱粉含量の測定について二つの異なった方法を用いてお り、ここで示されている実験データも非常に正確かつ詳細であ ると言える。私は本論文がこの方面の研究において良い手本に なり得ると考えている。

トランスジェニック植物により私たちが恩恵をこうむる までには、安全性の評価ならびに一般の人々にどう受け入れら れるかなど、克服しなければならない多くの問題がある。しか しながら、このようなすばらしい研究が人類の繁栄のために利 用できる日が早くやってくることを私は望んでやまない。

江崎グリコ株式会社・生物化学研究所

栗木 隆 